\title{
Pengelolaan Limbah Domestik Rumah Tangga Menjadi Biokomposter Mikroorganisme Dengan Metode Aerob-Anaerob
}

\author{
Management of Domestic Household Waste into Biocomposter Microorganisms by \\ Aerobic-Anaerobic Method \\ Yessi Meridian Dini ${ }^{1^{*}}$, Anis Aziza Zumroturida ${ }^{2}$, Siti Sela Nurhalisa ${ }^{3}$, Bagus Handi \\ Saputra $^{4}$ \\ 1,2,3,4 Jurusan D4 Teknik Pengendalian Pencemaran Lingkungan, Politeknik Negeri Cilacap, \\ Indonesia \\ Email : '1yessi.md13@gmail.com, ${ }^{2}$ anis_aziza@gmail.com, ${ }^{3}$ sela_nurhaliza@gmail.com, \\ bagushandi@gmail.com
}

Direview : 28 Januari 2020

Diterima : 25 Februari 2020

\begin{abstract}
Abstrak
Biokomposter ini merupakan salah satu bentuk pengelolaan sampah rumah tangga dengan mengolah sampah menjadi pupuk kompos. Pengomposan adalah proses dimana bahan organik mengalami penguraian secara biologis khususnya oleh mikroba yang memanfaatkan bahan organik sebagai sumber energi. Proses pengomposan berjalan secara aerob dan anaerob pada kondisi lingkungan tertentu yang disebut dengan proses dekomposisi. Tujuan dari penelitian ini untuk mengetahui pengolahan limbah domestik padat dengan menggunakan metode bio komposter dan mengetahui efektifitas penggunaan sisa kegiatan dapur dalam pengolahan limbah domestik (rumah tangga). Dalam penelitian ini menggunakan du acara yaitu secara aerob dan anaerob. Komposisi dari biokomposter anaerob (dengan udara) menggunakan penutup yang berlubang yaitu campuran komposter dari pupuk yang sudah jadi (diletakan paling bawah), kemudian selanjutnya kulit pisang yang sudah di gunting kecil-kecil terlebih dahulu, setelah kulit pisang dimasukan tanah liat dan terakhir dimasukan pupuk komposter yang sudah jadi. Sedangkan untuk komposisi dari biokomposter aerob (tanpa udara) menggunakan penutup tertutup yang pertama dimasukan yaitu pupuk komposter yang sudah jadi, kemudian memasukan kulit pisang yang sudah di iris kecil kecil dan diletakan dengan rapih di atas kompos, setelah itu dimasukan tanah liat yang diletakan di atas kulit pisang dan yang terakhir memasukan kulit pisang kembali yang diletakan diatas tanah liat. Hasil yang yang didapatkan adalah kompos berubah warna menjadi kecoklatan tua, suhu dan $\mathrm{pH}$ stabil dan aroma menyengat dari limbah sampah sudah mulai berkurang karena adanya proses pembentukan kompos yang sesuai.
\end{abstract}

Kata kunci: Anaerob; Aerob; Biokomposter; Kompos; Sampah .

\section{Abstract}

Biocomposter is one form of household waste management by processing waste into compost. Composting is the process by which organic material decomposes biologically, especially by microbes that utilize organic material as an energy source. The composting process runs aerobically and anaerobically in certain environmental conditions called the decomposition process. The purpose of this study was to determine the processing of solid domestic waste using the Bio Composter method and determine the effectiveness of the use of the remaining kitchen activities in domestic (household) waste treatment. In this study, using two programs, aerobic and anaerobic. The composition of the anaerobic biocomposter (with air) uses a perforated cover which is a mixture of composter from ready-made fertilizer (placed at the bottom), then then the banana skin that has been cut into small pieces first, after the banana peel is added to clay and finally put fertilizer ready-made composter. As for the composition of the aerobic biocomposter (without air), using a closed cover is first included composter fertilizer that is ready, then enter the banana skin that has been sliced into small pieces and placed neatly on the compost, then put the clay placed on top banana peels and finally put banana peels back on the clay. The results obtained are that the compost changes color to old brown, the temperature and $\mathrm{pH}$ are stable and the pungent aroma of waste has begun to diminish due to the appropriate composting process.

Keywords: Anaerobic; Aerob; Biocomposter; Compost; Rubbish. 


\section{PENDAHULUAN}

Sampah merupakan limbah yang bersifat padat yang terdiri dari bahan organik maupun anorganik yang sudah dianggap tidak berguna lagi dan harus dikelola dengan baik agar tidak mengganggu atau membahayakan lingkungan dan melindungi investasi pembangunan (Widyastuty, Adnan and Atrabina, 2019). Sampah yang digunakan dalam pembuatan kompos yaitu sampah kulit pisang. Kulit pisang merupakan bahan organik yang mengandung unsur kimia seperti magnesium, sodium, fosfor dan sulfur yang dapat dimanfaatkan sebagai pupuk organik. Pembuatan pupuk organik dengan bahan kulit pisang dapat dalam bentuk padat atau cair. Berdasarkan hasil analisis pada pupuk organik padat dan cair dari kulit pisang kepok, diketahui bahwa kandungan unsur hara yang terdapat di pupuk padat kulit pisang kepok yaitu, Corganik 6,19\%; N-total 1,34\%; P2O5 $0,05 \%$; K2O 1,478\%; C/N 4,62\% dan pH 4,8 sedangkan pupuk cair kulit pisang kepok yaitu, C-organik 0,55\%; N-total 0,18\%; P2O5 0,043\%; $\mathrm{K} 2 \mathrm{O} 1,137 \%$; C/N 3,06\% dan pH 4,5 (Rasmito dkk., 2019). Komposter merupakan perangkat (alat) untuk menghasilkan pupuk kompos, baik padat maupun cair (Santhiarsa, 2017). Komposter salah satu faktor penentu dalam proses pengomposan ataupun penentu kualitas kompos. Komposter di desain dengan memperhatikan sistem aerasi yang sempurna dengan mempertimbangkan adanya kecukupan sirkulasi udara untuk mensuplai kebutuhan oksigen bagi mikroorganisme dalam proses dekomposisi bahan organik yang akan dijadikan kompos (Arbi. dkk, 2019). Komposter yang dibuat ada 2 macam yaitu komposter aerobic dan komposter anaerobic. Komposter anaerob adalah kondisi tanpa udara (kedap udara) yang tidak memerlukan oksigen. Proses yang berlangsung dalam kondisi anaerob akan terhambat atau gagal apabila oksigen masuk atau tercampur ke dalam reaktor. Hal ini terjadi karena pada kondisi anaerob membutuhkan aktivitas bakteri pembentuk metan yang terdiri dari bakteri pembentuk gas yang tidak termasuk sebagai pengoksidasi metan (Sari, Iswanto, Indrawati, Trisakti, \& Pustaka, 2018). Sedangkan untuk komposter aerob adalah suatu proses yang berlangsung secara biologis dimana proses ini menggunakan oksigen. Sedangkan oksidasi bahan organik yang menggunakan molekul oksigen adalah pada proses utama sehingga menghasilkan energi kimia untuk mikroorganisme. Pengomposan adalah proses penguraian bahan- bahan organik secara biologis oleh mikroba- mikroba yang memanfaatkan bahan organik sebagai sumber energi (Trivana $\&$ Pradhana, 2017). Selama proses pengomposan memerlukan oksigen, $\mathrm{CO}_{2}, \quad \mathrm{H}_{2} \mathrm{O}$ dan menghasilkan energi panas. Kematangan kompos menjadi faktor yang menentukan kelayakan mutu kompos dan mempengaruhi apakah kompos dapat segera diaplikasikan ke dalam tanah. Kompos merupakan bentuk akhir dari bahan-bahan organik sampah domestik dan pasar yang telah mengalami proses penguraian. Pertumbuhan penduduk merupakan salah satu menyebab meningkatnya limbah padat dapat disebabkan oleh pertumbuhan. Meningkatnya jumlah limbah padat yang dihasilkan rumah tangga berkorelasi positif dengan jumlah penduduk disetiap daerah sehingga menyebabkan jumlah sampah yang dihasilkan rumah tangga juga semakin meningkat. Diperkirakan setiap rumah tangga di Indonesia dapat menghasilkan sampah sebanyak 0,52 $\mathrm{kg} /$ jiwa/hari. Kondisi tersebut tentunya menimbulkan banyak sekali permasalahan yang dapat berdampak secara langsung terhadap mahluk hidup disekitarnya. Sehingga perlu dilakukanya suatu upaya pemanfaatan sampah yang terpadu dan dilakukan secara masal sehingga pengurangan jumlah sampah dapat teratasi. Pemanfaatan sampah organik yang banyak sekali dihasilkan dari kegiatan-kegiatan domestik dapat dilakukan suatu pemanfaatan seperti pembuatan kompos melalui metode Biokomposter. Sehingga metode ini dirasa cukup efektif untuk dilakukan dan sebagai objek kegiatan praktikum mata kuliah pengelolaan limbah domestik.

\section{METODE PENELITIAN}

Pembuatan Biokomposter ini didasari dari sumber data yang diperoleh berupa data sekunder dari jurnal ataupun literatur yang sudah ada dan eksperimen yang telah dilakukan untuk pengolahan data. Tempat pelaksanaan pembuatan alat dilakukan di Kampus Politeknik Negeri Cilacap dengan waktu yang kami butuhkan selama 5 minggu. Metode komposter dengan penambahan bakteri (activator) dari sampah kulit pisang yang merupakan material sisa yang tidak diinginkan. 


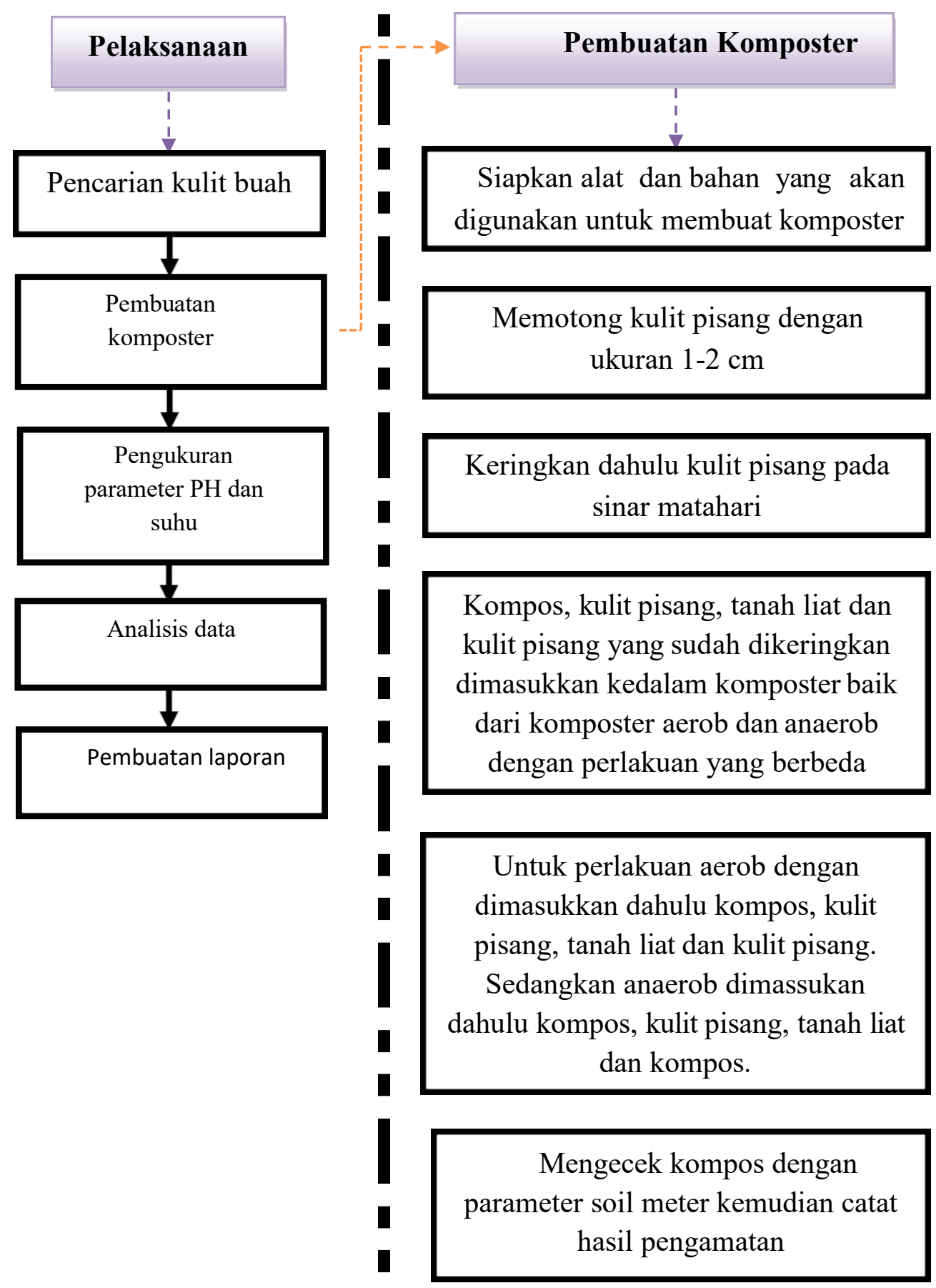

Gambar 1. Sketsa Prosedur Kerja

\section{HASIL DAN PEMBAHASAN}

Pada prosesnya pengomposan dilakukan mulai pada tanggal 6 Desember 2019 yang dilakukan di kampus Politeknik Negeri Cilacap. Pengomposan ini dibagi menjadi 2 bagian yaitu kompos aerob dan anaerob.. Setelah itu pukul 11.45 WIB dilakukan pengukuran suhu, kelembaban, $\mathrm{pH}$ dan didapatkan hasil suhu untuk kompos aerob sebesar $30^{\circ} \mathrm{C}$ dan kelembaban dry $^{+}$dengan hasil $\mathrm{pH} 7$ (netral) dengan tekstur granul berwarna coklat dan bau busuk. Untuk kompos anaerob didapatkan hasil suhu sebesar $30^{\circ} \mathrm{C}$ dan kelembaban dry ${ }^{+}$dengan hasil pH 7 (netral juga) dengan granul berwarna coklat dan bau busuk. Pada tanggal 20 Desember 2019 pukul 09.10 WIB dilakukan pengukuran suhu, kelembaban, pH. Dan didapatkan hasil suhu untuk kompos aerob sebesar $26^{\circ} \mathrm{C}$ dan kelembaban dry $^{+}$dengan hasil pH 7 (netral) dengan tekstur berjamur berwarna coklat dan bau busuk. Berikut ini desain susunan 
pengolahan limbah domestik dengan Biokomposter secara aerob :

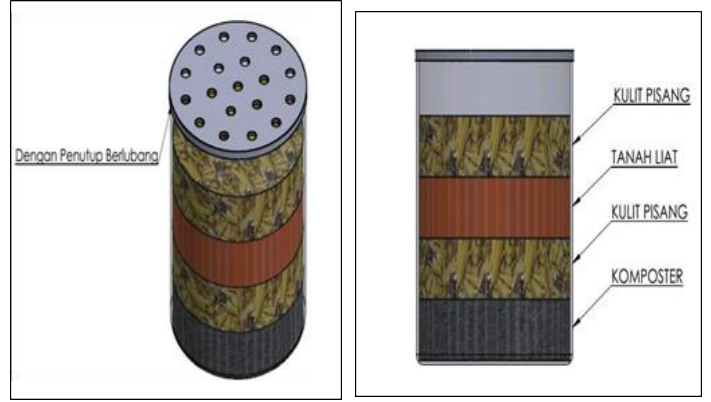

Gambar 2. Desain Bikomposter secara Aerob

Untuk kompos anaerob didapatkan hasil suhu sebesar $27^{\circ} \mathrm{C}$ dan kelembaban dry ${ }^{+}$dengan hasil pH 7 (netral) dengan tekstur lunak berwarna coklat dan bau busuk. tanggal 3 Januari 2020 pukul 09.20 WIB dilakukan pengukuran suhu, kelembaban, $\mathrm{pH}$ pada kompos anaerob didapatkan hasil suhu sebesar $28^{\circ} \mathrm{C}$ dan kelembaban dry $^{+}$dengan hasil $\mathrm{pH} 7$ (netral). Pada kompos aerob dengan tekstur granul berwarna hitam kecoklatan dan bau tidak menyengat. Sedangkan pada kompos anaerob tekstur sedikit berjamur berwarna hitam kecoklatan dan bau tidak menyengat. Tanggal 10 Januari 2020 pukul 09.45 WIB dilakukan pengukuran suhu, kelembaban, pH. Dan didapatkan hasil suhu untuk kompos aerob sebesar $26^{\circ} \mathrm{C}$ dan kelembaban dry ${ }^{+}$dengan hasil pH 7 (netral) dengan tekstur granul berwarna coklat dan bau busuk. Untuk kompos anaerob didapatkan hasil suhu sebesar $27^{\circ} \mathrm{C}$ dan kelembaban dry $^{+}$dengan hasil $\mathrm{pH} 7$ (netral) dengan tekstur granul berwarna hitam kecoklatan dan bau busuk. Tanggal 15 Januari 2020 pukul 10.30 WIB dilakukan pengukuran suhu, kelembaban, pH. Dan didapatkan hasil suhu untuk kompos aerob sebesar $29^{\circ} \mathrm{C}$ dan kelembaban dry $^{+}$dengan hasil $\mathrm{pH} 7$ (netral) dengan tekstur granul berwarna coklat dan bau busuk. Untuk kompos anaerob didapatkan hasil suhu sebesar $29^{\circ} \mathrm{C}$ dan kelembaban dry ${ }^{+}$dengan hasil $\mathrm{pH} 7$ (netral) dengan tekstur granul berwarna hitam kecoklatan dan bau busuk. Berikut ini desain susunan biokomposter secara anaerob :
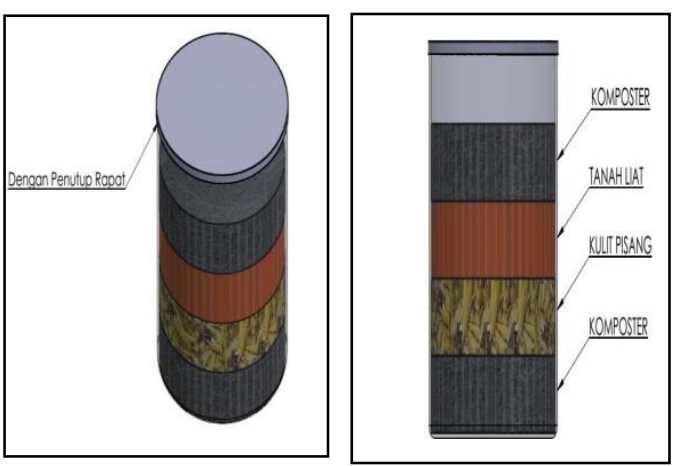

Gambar 3. Desain Biokomposter secara Anaerob

Menurut hasil pengamatan yang telah dilakukan dari praktek pembuatan biokomposter didapatkan karakteristik fisik kompos yang telah dibuat Jika proses pembuatan kompos berjalan dengan normal, maka tidak menghasilkan bau yang menyengat. Walaupun demikian, dalam pembuatan kompos tidak akan terbebas sama sekali dari adanya bau. Kompos yang sudah matang dapat diketahui dari baunya yang seperti bau tanah. Berdasarkan hasil pengamatan, kompos yang dihasilkan masih berbau busuk sehingga dapat dikatakan kompos masih belum matang. Warna merupakan salah satu indikator untuk mengetahui kematangan kompos yaitu cokelat kehitam-hitaman, hasil pengamatan, kompos aerob dan anaerob yang dihasilkan kebanyakan masih berwarna coklat dan hitam kecoklatan bukan coklat kehitaman sehingga dapat dikatakan kompos tersebut belum matang. Untuk tekstur ukuran partikel sampah yang digunakan sebagai bahan baku pembuatan kompos harus sekecil mungkin untuk mencapai efisiensi aerasi dan supaya lebih mudah dicerna atau diuraikan oleh mikroorganisme. Semakin kecil partikel, semakin luas permukaan yang dicerna sehingga pengurai dapat berlangsung dengan cepat .Jika proses pembuatan kompos berjalan dengannormal, maka tekstur kompos remah dan tidak menggumpal. pada kompos yang sudah matang, bentuk fisiknya menyerupai tanah yang berwarna kehitaman. Menurut hasil pengamatan, kompos yang dihasilkan kebanyakan masih bertekstur granul dan berjamur dikarenakan partikel masih besar dan kompos masih belum matang.

Lama waktu pengomposan tergantung pada karakteristik bahan yang dikomposkan, metode yang digunakan dan keberadaan aktivator pengomposan.Secara alami pengomposan akan berlangsung dalam waktu beberapa minggu sampai 2 tahun hingga kompos benar-benar matang. Menurut hasil pengamatan yang telah dilakukan waktu pengomposan yang hanya 
dilakukan selama 1 bulan lebih yaitu sekitar 6 minggu .Waktu untuk pengomposan ini sebenarnya sudah cukup untuk membuat kompos matang. Namun yang terjadi kompos belum semuanya matang dan teksturnya juga masih granul belum tercampur sempurna serta ada belatung dalam proses pengomposan. Mungkin terjadi karena pencampuran yang mungkin dapat menyebabkan proses pengomposan tidak berjalan sempurna. Kekurangan dari kompos berbahan pupuk komposter, kulit pisang dan tanah liat ini dapat dilihat dari metode pengomposan yang digunakan yaitu metode aerob dan anaerob sama sama menimbulkan bau busuk selama proses pengomposan dan terdapat sedikit hewan-hewan kecil akan tetapi bukan belatung juga terdapat jamur pada kulit pisangnya. Sedangkan kelebihan dalam pembuatan kompos ini adalah bahan yang digunakan mudah didapat.Berikut ini tabel 1 dan tabel 2 berdasarkan hasil pengamatan.

Tabel 1. Data Hasil Pengukuran Parameter pH dan suhu pada Biokomposter

\begin{tabular}{|c|l|c|c|c|c|}
\hline \multirow{2}{*}{ No } & \multirow{2}{*}{ Pemeriksaan } & \multicolumn{2}{|c|}{ Aerob } & \multicolumn{2}{c|}{ Anaerob } \\
\cline { 3 - 6 } & & $\mathbf{p H}$ & $\begin{array}{c}\text { Suhu } \\
\left({ }^{\circ} \mathbf{C}\right)\end{array}$ & $\mathbf{p H}$ & $\begin{array}{c}\text { Suhu } \\
\left({ }^{\circ} \mathbf{C}\right)\end{array}$ \\
\hline 1 & Hari ke 1 & 7 & 30 & 7 & 30 \\
\hline 2 & Hari ke 2 & 7 & 26 & 7 & 27 \\
\hline 3 & Hari ke 3 & - & - & 7 & 28 \\
\hline 4 & Hari ke 4 & 7 & 26 & 7 & 27 \\
\hline 5 & Hari ke 5 & 7 & 29 & 7 & 29 \\
\hline
\end{tabular}

Tabel 2. Kondisi Fisik Biokomposter

\begin{tabular}{|c|c|c|c|c|c|c|c|c|}
\hline \multirow{2}{*}{ No } & \multirow{2}{*}{ Pemeriksaan } & \multirow{2}{*}{$\begin{array}{l}\text { Pukul } \\
\text { (WIB) }\end{array}$} & \multicolumn{3}{|c|}{ Aerob } & \multicolumn{3}{|c|}{ Anaerob } \\
\hline & & & Tekstur & Warna & Bau & Tekstur & Warna & Bau \\
\hline 1 & Hari 1 & 11.45 & Granul & Coklat & Busuk & Grandul & Coklat & Busuk \\
\hline 2 & Hari 2 & 09.10 & Berjamur & Coklat & Busuk & Lunak & Coklat & Busuk \\
\hline 3 & Hari 3 & 09.20 & Grandul & $\begin{array}{c}\text { Hitam } \\
\text { Kecoklatan }\end{array}$ & $\begin{array}{c}\text { Tidak } \\
\text { Menyengat }\end{array}$ & $\begin{array}{c}\text { Sedikit } \\
\text { Berjamur }\end{array}$ & $\begin{array}{c}\text { Hitam } \\
\text { Kecoklatan }\end{array}$ & $\begin{array}{c}\text { Tidak } \\
\text { Menyengat }\end{array}$ \\
\hline 4 & Hari 4 & 09.45 & Granul & Coklat & Busuk & Granul & $\begin{array}{c}\text { Hitam } \\
\text { Kecoklatan }\end{array}$ & Busuk \\
\hline 5 & Hari 5 & 10.30 & Granul & Coklat & Busuk & Granul & $\begin{array}{c}\text { Hitam } \\
\text { Kecoklatan }\end{array}$ & Busuk \\
\hline
\end{tabular}

\section{KESIMPULAN}

Dari hasil penelitian dan analisis data yang telah dilakukan dapat digunakan metode pengomposan secara anaerob (tanpa menggunakan oksigen) yang biasanya akan membutuhkan bioaktivator sebagai inokulan pemacu pertumbuhan dan pembungaan tanaman dengan larutan EM4, sedangkan aerob (memerlukan oksigen) yang berguna untuk menghasilkan energi kimia bagi mikroorganisme. Dalam pengomposan ini juga dipengaruhi oleh faktor pengaturan kelembaban, pengaturan suhu dan derajat keasamaan $(\mathrm{pH})$. Kematangan kompos menjadi faktor yang menentukan kelayakan mutu kompos pada hasil akhir dari bahan-bahan organik sampah domestik dan pasar yang telah mengalami proses penguraian. Kematangan tersebut ditunjukkan dengan beberapa hal antara lain : dicium, warna kompos, penyusutan, tes kantong plastik, tes perkecambahan, jumlah benih sama, suhu, kandungan air kompos. Disamping itu, dalam penelitian ini digunakan adanya proses fermentasi yang merupakan suatu proses perubahan kimia pada substrat organik melelui aktivitas enzim yang dihasilkan oleh mikroorganisme. Hasil penelitian pembuatan kompos yang telah diperoleh selama 5 (lima) minggu berdasarkan faktor-faktor lingkungan adalah kompos sudah tidak berbau busuk, 
tekstur kompos sudah tidak berbentuk granula dan warna kecoklatan tua. Berdasarkan hasilnya kompos yang telah matang sesuai dengan kondisi lingkungan terdapat pada suhu $26^{\circ} \mathrm{C}$ dengan derajat keasaman $(\mathrm{pH})$ sebesar 7 .

\section{DAFTAR PUSTAKA}

Arbi, Y. dkk. (2019). Rancang Bangun Komposter Anaerob Untuk Mengolah Sampah Menjadi Pupuk Kompos Dan Pupuk Cair Di Nagari Parambahan. Jurnal aerasi. 1(2), 22-26.

Rasmito, A. dkk. (2019). Pembuatan Pupuk Organik Cair dengan Cara Fermentasi Limbah Cair Tahu, Starter Filtrat Kulit Pisang dan Kubis, dan Bioaktivator EM4. Jurnal iptek. 55-62. https://doi.org/10.31284/j.iptek.2019.v23i1

Trivana, L., \& Pradhana, A. Y. (2017). Optimalisasi Waktu Pengomposan dan Kualitas Pupuk Kandang dari Kotoran Kambing dan Debu Sabut Kelapa dengan Bioaktivator PROMI dan Orgadec. Jurnal Sain Veteriner, 35(1), 136. https://doi.org/10.22146/jsv.29301

Saraswati, R., Heru, R., Tentara, J., No, P., \& Barat, J. (2017). Percepatan Proses Pengomposan Aerobik Menggunakan Biodekomposer / Acceleration of Aerobic Composting Process Using Biodecomposer. Perspektif, 16(1), 44- 57. https://doi.org/10.21082/psp.v16n1.2017.44. 
Jurnal Pengendalian Pencemaran Lingkungan (JPPL)

Vol. 2 No.01 Maret 2020

DOI : 10.35970/jppl.v2i1.123

Corresponding Author : yessi.md13@gmail.com 